\title{
Address at a symposium in honour of former Rector and Professor Emeritus Guðmundur K. Magnússon.
}

\section{Dr. Kristin Ingolfsdottir, Rector of the University of Iceland ${ }^{1}$}

Distinguished guest of honour, Gudmundur K. Magnusson, ladies and gentlemen!

For us, who are gathered here to honour Dr. Gudmundur K. Magnusson, former Rector and Professor Emeritus, his brilliant career raises feelings of both respect and pride. Dr. Magnusson retired from his position at the University of Iceland on 1 May of this year, but his career has been both diverse and singularly successful. Naturally our feelings are mixed when such a strong leader retires. We will miss him, but at the same time we are thankful for his invaluable efforts on behalf of the University of Iceland.

Dr. Magnusson came to the University upon graduation from Uppsala University and studies at the Massachusetts Institute of Technology (MIT) in Boston, USA. He was a lecturer at Uppsala University for a few years, but became a professor at the University of Iceland in 1968, so the University has benefited from his work for close to 40 years. Dr. Magnusson has held many positions of responsibility for the University of Iceland. Immediately in his second year of employment, he became the Dean of the Faculty of Business, as it was known at the time, and later became Rector for a period of six years, from 1979 to 1985.

Dr. Magnusson is one of the fathers of formal education in economics in Iceland. The programme in economics at the Faculty of Business was founded on his initiative, and evolved into the founding of the Department of Economics. Dr. Magnusson was also a driving force in the foundation of the Institute of Economic Studies; he was its first director and from the beginning set the course for its operation. The flourishing teaching and research in economics at the University of Iceland is largely thanks to the pioneering efforts of Dr. Magnusson.

For many years, Dr. Magnusson was sought after and influential as advisor to Icelandic politicians, both in matters of industrial development and economics. Dr. Magnusson also sat on the Board of Directors of the Nordic Investment Bank, and as its Chairman for a couple of years. He also sat on the Board of Directors of the Central Bank of Iceland for many years. Dr. Magnusson has played an important part in establishing the role of economics in society and in garnering the respect that economics enjoys as a field of science in Iceland.

Dr. Magnusson is a respected scholar in his field. He has written books and numerous articles on economics, especially in risk management, public finance and energy economics. His strong academic standing has allowed Dr. Magnusson to take on important positions of responsibility for various scientific funds in Iceland and

1 English translation: M.A. Thora Christiansen. 
abroad. As the Chairman of the Union of Professors he was influential in the creation of the system of quality control for research utilised by the University of Iceland to this day. Without a doubt this system has played a key role in the rapid increase seen in research activity at the University in recent years. It took a great deal of foresight and daring to advocate the quality control system and introduce the way of thinking on which it is founded.

Thorolfur Thorlindsson will cover Dr. Magnusson's term as rector; however, I cannot but mention a few key issues. During Dr. Magnusson's term as rector, the number of students grew considerably; an increase of 50\% between 1979 and 1985. As Rector, Dr. Magnusson placed great emphasis on furthering research, especially service research with the aim of strengthening the ties with the business community. Dr. Magnusson also directed the making of agreements with prominent research universities abroad, e.g. the University of Minnesota, but we celebrated 30 years of successful cooperation between the universities this spring. This was the first cooperation agreement made by the University of Iceland with a university abroad. It was also thanks to Dr. Magnusson's foresight that the ground was paved for programmes of continuing education at the University of Iceland. His role in the vibrant continuing education effort carried out by the University today cannot be overstated. Right from the beginning, when Dr. Magnusson gave his first address as Rector at the graduation ceremony on 27 October 1979, his ambition, so characteristic for his whole career, was evident - ambition on behalf of the Icelandic community and a clear vision of how the University of Iceland can contribute to the betterment of society, and thus, to the betterment of the standard and quality of living for Icelanders. This is the ideology that guides our work today.

Dr. Magnusson has been very active in social affairs. In particular, he has made great achievements on behalf of the Neskirkja parish. For many years he was chairman of the parish council, where he organised reconstruction of the church and the construction of a congregation hall. It was evident to all that the finances of Neskirkja were very competently managed during Dr. Magnusson's term as chairman. A further evidence of the universal trust that Dr. Magnusson enjoys in all his work is his appointment as Member of the Executive Council of the Lutheran Church of Iceland and the General Synod. Dr. Magnusson stood like a rock in the church life and I know that he and his vigorous work ethic are greatly missed.

Dr. Magnusson has always been a fan of sports and healthy living. He was a regular player in the faculty volleyball and basketball sessions right up to his retirement. I am told that there his competitive spirit soared - enough to make members of opposing teams wince! But a competitive spirit is a great benefit in the work for the University. It has no doubt been a driving force in Dr. Magnusson's work and brought the University of Iceland and the Icelandic community the success enjoyed by us all today.

Dr. Magnusson, our sincere thanks for your unique contribution to the University of Iceland and for sharing with us over half of your life! I know that I speak for all of us when I wish you continued good fortune and success in all of your endeavours. 